\section{Esophageal microabscesses: an alternative presentation of eosinophilic esophagitis}

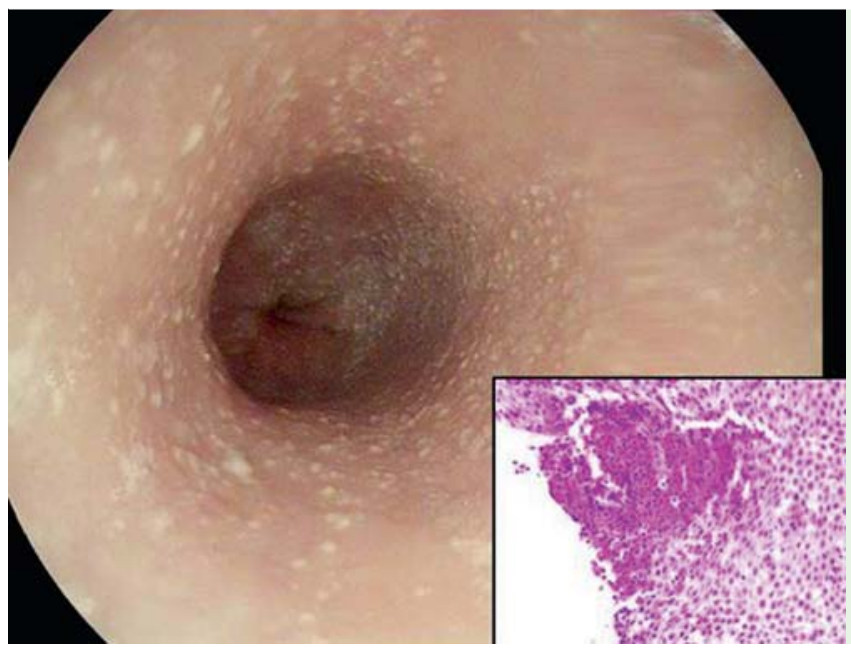

Fig. 1 Eosinophilic esophagitis with eosinophilic micro abscesses in a 33-yearold man. Endoscopy showed pale esophageal mucosa with multiple small plaques in the distal esophagus. Inset: The eosinophils, which are characterized by the intense red color and lobulated nucleus, are organized in an abscess surrounded by squamous cells.

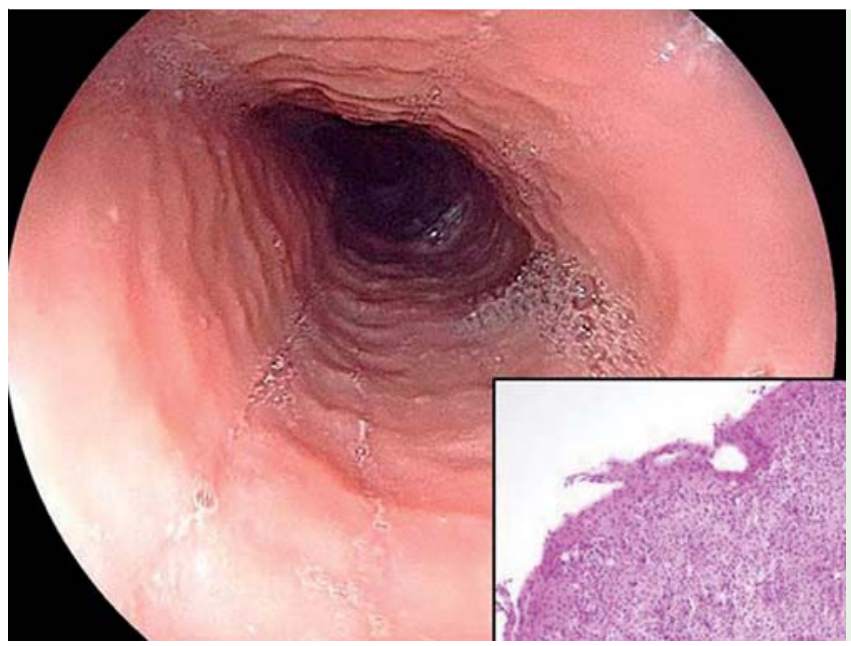

Fig. 2 Eosinophilic esophagitis: typical endoscopic presentation with notable esophageal rings (trachealization), and longitudinal furrows. Inset: The eosinophils are dispersed between squamous cells. fractory heartburn, central chest pain that is not responsive to antacids, and upper abdominal pain. It is a disease affecting all age groups, with a male predominance [1 - 3].

Typically, endoscopy reveals esophageal rings (so-called trachealization or feline esophagus) and longitudinal furrows as presented in Fig. 2 (from a patient with long-standing episodes of recurrent food impaction and dysphagia, and a peak eosinophil count of $110 / \mathrm{hpf}$ at biopsy). Other endoscopic features include white plaques, strictures, narrowing of the esophagus, and pallor or decreased vasculature [4].

Eosinophil-predominant inflammation on biopsy is generally considered to be present when there is a minimum of 15 eosinophils per hpf on microscopy. It is important to exclude alternative causes of esophageal eosinophilia such as gastroesophageal reflux disease, celiac disease, Crohn's disease, infection, hypereosinophilic syndrome, achalasia, drug hypersensitivity, vasculitis, pemphigoid vegetans, connective tissue disease, and graftversus-host disease [5].

Endoscopy_UCTN_Code_CCL_1AB_2AC_3AZ

Competing interests: None

\section{Kristof Verraes ${ }^{1}$, David Strybol ${ }^{2}$, Ingrid Demedts ${ }^{1}$, Raf Bisschops ${ }^{1}$, Philip Roelandt ${ }^{1}$}

${ }^{1}$ Gastroenterology Department, UZ Leuven, Leuven, Belgium

2 Pathology Department, UZ Leuven, Leuven, Belgium

\section{References}

1 Sgouros SN, Bergele C, Mantides A. Eosinophilic esophagitis in adults: a systematic review. Eur J Gastroenterol Hepatol 2006; 18: 211-217

2 Pasha SF, DiBaise JK, Kim HJ et al. Patient characteristics, clinical, endoscopic, and histologic findings in adult eosinophilic esophagitis: a case series and systematic review of the medical literature. Dis Esophagus 2007; 20: $311-319$

3 Kapel RC, Miller JK, Torres $C$ et al. Eosinophilic esophagitis: a prevalent disease in the United States that affects all age groups. Gastroenterology 2008; 134: 1316-1321 
4 Kim HP, Vance RB, Shaheen NJ et al. The prevalence and diagnostic utility of endoscopic features of eosinophilic esophagitis: a meta-analysis. Clin Gastroenterol Hepatol 2012; 10: 988 -996

5 Liacouras CA, Furuta GT, Hirano I et al. Eosinophilic esophagitis: updated consensus recommendations for children and adults. J Allergy Clin Immunol 2011; 128: 3-20
Bibliography

Dol http://dx.doi.org/

10.1055/s-0034-1391337

Endoscopy 2015; 47: E123-E124

(c) Georg Thieme Verlag KG

Stuttgart · New York

ISSN 0013-726X
Corresponding author

Philip Roelandt, MD, PhD

Gastroenterology Department

UZ Leuven

Herestraat 49

3000 Leuven

Belgium

Fax: +32-16-344387

philip.roelandt@uzleuven.be 